\title{
Knowledge Gaps or Change of Distribution Ranges? Explaining New Records of Birds in the Ecuadorian Tumbesian Region of Endemism
}

\author{
Adrian Orihuela-Torres ${ }^{1,2, *} \mathbb{C}^{\mathbb{C}}$, Boris Tinoco ${ }^{3}$, Leonardo Ordóñez-Delgado ${ }^{1,4} \mathbb{C}^{\mathbb{C}}$ and \\ Carlos Ivan Espinosa ${ }^{1}$ (D) \\ 1 Laboratorio de Ecología Tropical y Servicios Ecosistémicos (EcoSs-Lab), Departamento de Ciencias \\ Biológicas, Universidad Técnica Particular de Loja, Loja 1101608, Ecuador; lyordonez2@utpl.edu.ec (L.O.-D.); \\ ciespinosa@utpl.edu.ec (C.I.E.) \\ 2 Departamento de Biología Aplicada, Universidad Miguel Hernández, Avenida de la Universidad, \\ 03202 Elche, Spain \\ 3 Escuela de Biología, Universidad del Azuay, Cuenca 0101981, Ecuador; btinoco@uazuay.edu.ec \\ 4 Programa de Doctorado en Conservación de Recursos Naturales. Escuela Internacional de Doctorado, \\ Universidad Rey Juan Carlos, 28933 Madrid, Spain \\ * Correspondence: adrian.orihuela89@gmail.com
}

Received: 27 November 2019; Accepted: 4 February 2020; Published: 7 February 2020

\begin{abstract}
The change in the distribution range is a common response of various species facing the effects of anthropogenic global change. We used new distribution records of birds reported during the last two decades from the Ecuadorian part of the Tumbesian region (western Ecuador and northwestern Peru) available through a bibliographic review, together with our own field data collected during 2014-2019, and generated a methodology that explored whether these new reports are likely due to knowledge gaps or changes in the distribution range. We classified the species with new records as either Change of distribution range, Likely change of distribution range, Accidental, Knowledge gap, or Undetermined based on information about the distribution area, species conspicuousness, and dynamics of the records in the new location. We gathered data for 46 bird species newly reported in the Ecuadorian Tumbesian region in the last two decades. Of this, 35\% of species were classified as Accidental, 24\% as Knowledge gaps, $22 \%$ as Change of distribution range, $15 \%$ as Undetermined, and $4 \%$ as Likely change of distribution range. Species classified as Change of distribution range were mostly aquatic. Terrestrial species were mostly classified as Knowledge gap, while aquatic species were mostly classified as Accidental. Our protocol was validated using species which are known to have modified their distribution range in the Palearctic region, all of which were correctly classified by our methodology. The proposed method was precise and easy to apply and will allow us to better understand how species respond to anthropogenic global change, especially in areas where long-term studies are scarce, such as in tropical areas.
\end{abstract}

Keywords: distribution; dry tropical forest; Ecuador; global change; species movement

\section{Introduction}

Anthropogenic global change is considered one of the greatest threats to biodiversity on the planet [1-4]. For instance, the current extinction rate of birds is at least 1000 times higher than the background rate of species extinctions [5]. However, species are able to develop multiple strategies in response to global change, including modifications in their distribution range [6-9]. Changes in the distribution of a species can be the result of extinction in the areas affected by strong environmental modifications, and/or movements towards areas that maintain favorable 
conditions [10-12]. Quantifying the extent of the species' response to prevailing environmental conditions is essential to develop effective conservation actions [13].

Birds are considered efficient indicators of global change [14]. Several studies have shown that multiple bird species are moving towards the poles and at higher elevations, which fits the theoretical predictions of global warming effects $[12,15,16]$. However, most of these studies have been carried out in North America [17-21] and Europe [22-26], with hardly any such information available for the Neotropics $[12,27,28]$, one of the most species-rich regions of the world. The scarcity of long-term studies in the Neotropical region [29] limits our capacity to understand how species are coping with the global climate change in this region [30].

The changes brought on by global warming are predicted to be less severe in tropical than temperate regions $[16,31]$. However, species in the tropical environments usually have higher levels of specialization, which increases their sensitivity to global warming effects [7,12,32,33]. Niche specialization is particularly high in the seasonally dry tropical forests, where species have developed unique strategies to tolerate the stressful climatic conditions [34].

Located in western Ecuador and northwestern Peru, the Tumbesian region is one of the areas with the highest concentration of endemic species in the world [35]. Unfortunately, it is also facing numerous conservation threats, as a consequence of an intense anthropogenic disturbance associated to agriculture expansion, urbanization, and tree logging [36-39]. Additionally, it is expected that the tropical dry forests of South America will be strongly affected by global warming due to the predicted reduction in precipitation [40]. This situation has prompted a surge in the interest of researchers in this region, resulting in an increase in the number of scientific studies involving several taxa. Among them, the birds have received a special emphasis [41]. For example, knowledge of distribution of birds in the Tumbesian region has increased during the last years e.g., [42-51], and reports of new records are becoming more common e.g., [42,44,52-54]. Although this seems to be an expected consequence of the increase in research, some authors suggest that these new records may be an evidence of changes in distribution ranges of species, triggered by the anthropogenic global change $[20,21,55]$. For instance, there are reports of the presence of aquatic birds in Ecuador in areas where they historically have never been recorded [56-62].

Based on new ornithological records reported in the Tumbesian region, we propose a methodological protocol that allows exploring to what extent records of a species in a new location can be explained by knowledge gaps, or by actual changes in the distribution range of a species. Specifically, we are interested in: (1) Generating a methodological protocol that can be used to explore the nature of new records of a species within a given region, (2) using this protocol to classify new bird records reported the last two decades in the Ecuadorian part of the Tumbesian region, and (3) evaluating if the classification of species is associated with their habitat (terrestrial or aquatic).

\section{Materials and Methods}

\subsection{Study Area}

The Tumbesian region comprises a narrow strip of land between the Pacific Ocean and the Andes, covering $87,000 \mathrm{~km}^{2}$ of southwestern Ecuador and the extreme northwest of Peru. This region covers generally altitudes from sea level to $2000 \mathrm{~m}$ above sea level (a.s.l.), although it reaches at some points maximum altitudes of $3000 \mathrm{~m}$ a.s.l. [35] (Figure 1). The climate is characterized by a distinct seasonality, with a rainy season of five months (January-May), when $80 \%$ of the annual rainfall occurs, followed by a dry period that lasts for the rest of the year, with less than $10 \mathrm{~mm}$ monthly precipitation [63].

The Tumbesian region is one of the areas with the highest bird endemism worldwide (EBA) [64,65]. However, this region is seriously threatened, only approx. $29 \%$ of the original dry forest extent remains in the Ecuadorian part of the Tumbesian region [66]. 


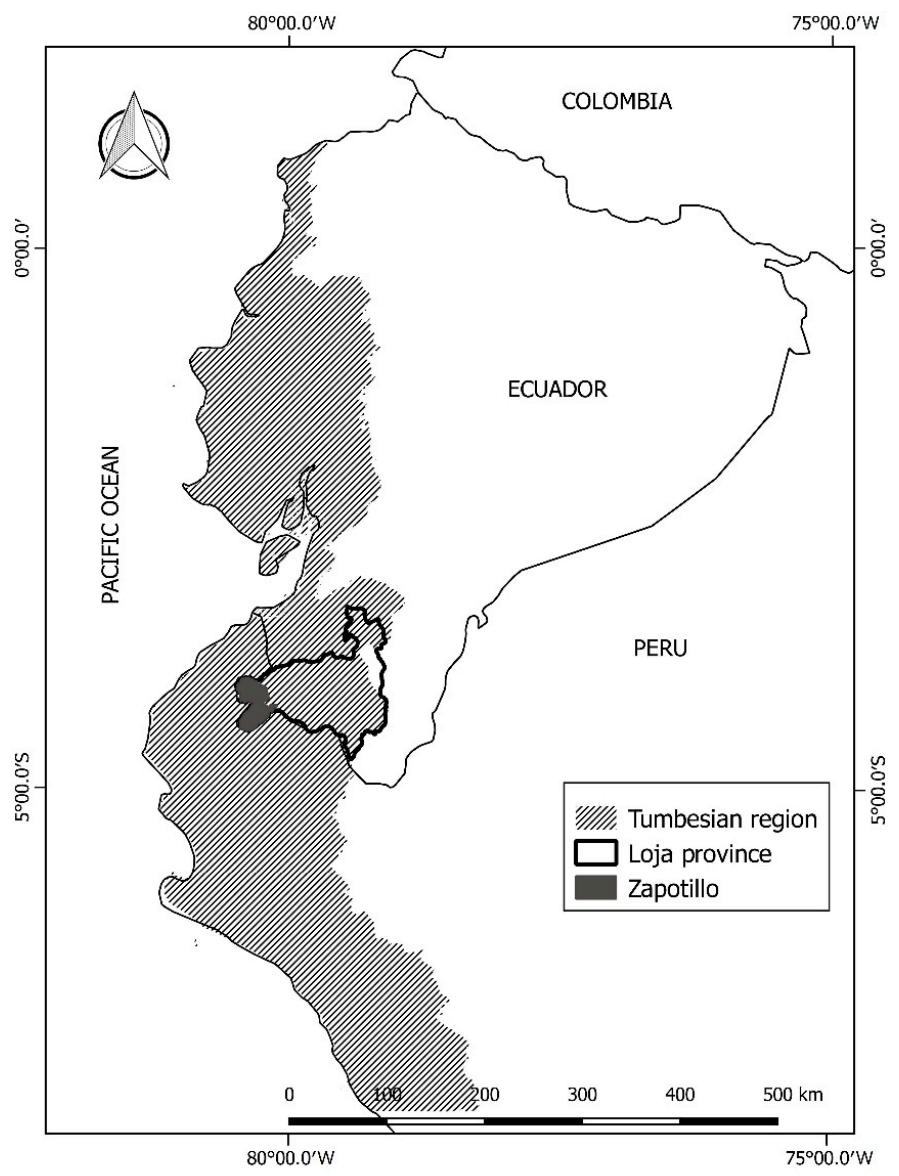

Figure 1. Map of the Tumbesian region and the canton Zapotillo in the province of Loja, Ecuador.

\subsection{Sampling and Data Collection}

Through bibliographic review and field work, we collected information on new records of birds in the Ecuadorian part of the Tumbesian region in the last two decades. Bibliographic records of bird species reported for Ecuador in the Tumbesian region were compiled from the Ecuadorian Committee of Ornithological Records (CERO) [67-69], which has gathered new or unusual records of bird species in Ecuador in the last two decades. Additionally, we included publications of new records in Zapotillo canton and Loja province, resulting from our own fieldwork. Fieldwork data was part of a long-term research program, conducted in the southwestern dry forests of Ecuador starting in 2014, and includes bird studies using captures with mist nets, point count observations, and random records.

\subsection{Category Assignment}

After generating a database including all the new bird species records in the Ecuadorian part of the Tumbesian region for the last two decades, each species was assigned a category based on interpolating values of three indicators: Distribution Area, Conspicuousness, and Recording Dynamics.

Distribution Area: Evaluates two aspects of the spatial location of the new record. Unusual and abnormal records may denote changes in environmental or habitat conditions. The distribution criteria evaluates if the report is in the elevation, longitude, and latitude range known for the species. The habitat criteria assigns new reports as usual or unusual based on Ridgely and Greenfield [70] and del Hoyo et al. [71], taking into account the known type of habitat inhabited by the species.

Conspicuousness: This indicator was also based on two criteria, abundance and detectability of the species. We expected that those species naturally more abundant will be more likely to be registered than species with smaller population sizes. We classified the species as abundant or rare according to Ridgely and Greenfield [72] and McMullan and Navarrete [73]. A species was considered abundant 
when in the literature reference it was classified as quite common, common, or abundant; otherwise, it was considered as rare. Additionally, detectability was assessed in relation to plumage color patterns, vocalizations, or behavior for both genders or for at least one. For example, species with intense colors are likely to have a higher detectability than species with bland or cryptic colors. Based on this, each species was classified as highly detectable or poorly detectable. We used bibliography $[70,72,73]$ for determining levels of detectability. We assumed that, if the species is highly detectable and/or with high abundance, its conspicuousness increases.

Dynamic of Records: Evaluates if the records of a species in a given location are unique and scarce, or if there is a pattern of a temporary increase in the number of records. The information about dynamics of records was obtained from Ridgely and Greenfield [70,72], Freile et al. [67], Nilsson et al. [68], Ordoñez-Delgado et al. [42], Freile et al. [69], McMullan and Navarrete [73], and eBird [74]. The increase in the number of records could be associated with a process of colonization of new areas and, therefore, it would be an indication that the species is moving. However, an increase in records can also be associated with an increase in the number of studies (see Table 1 for a more specific description of each indicator).

Table 1. Description of the indicators and criteria used for the classification of the new records of birds reported in the Ecuadorian part of the Tumbesian region in the last two decades.

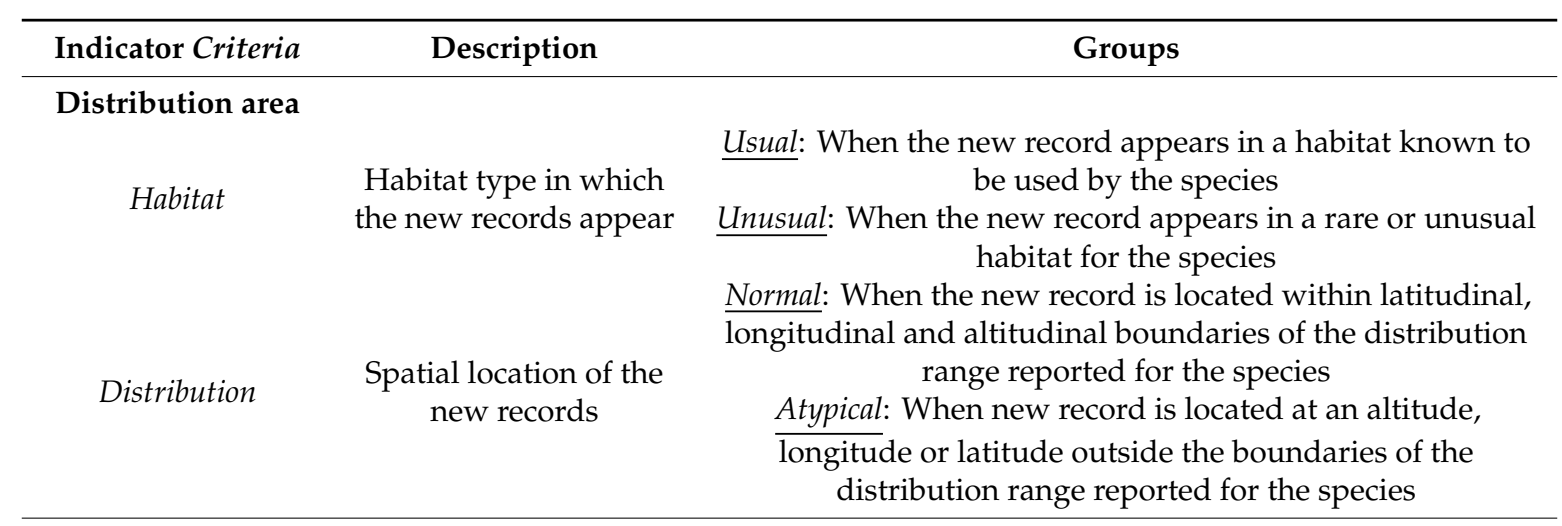

Conspicuousness

Abundance

Abundance of the species in the country

The ease with which the species can be Detectability detected and/or the possibility of misidentifications

Rare: When the species is considered as unusual, rare, incidental, accidental or hypothetical for the country Abundant: When the species is considered as quite common, common or abundant for the country

High: When the species is easy to detect and/or with low

probability of being confused with other species that occur in the habitat where it was recorded. A species is highly detectable when it has behaviors or colors that facilitate visualization, and is easy to observe or hear (e.g.,

Phoenicopterus chilensis, Aramus guarauna or Elanus leucurus) Low: When the species is difficult to detect and/or has high probability of being confused with other species that occur

in the habitat where it was recorded. These are species which usually remain hidden and are difficult to observe or hear. In other cases, species with similar morphology or vocalizations occur at the location where it was recorded, and may be misidentified (e.g., Calidris sp. or many tiranids)

\section{Dynamics of} records

Dynamic

Number of records of the species at the new location
Scarce: When the species has few records in the area/habitat where new records have been reported and records are not increasing over time

Increasing: When records have been increasing in the area/habitat where the species has been found in recent years 
The relationship among the proposed indicators allowed us to make a classification protocol of new records into five categories: Change of distribution range, Likely change of distribution range, Accidental, Knowledge gap, and Undetermined. (1) Change of distribution range: Species which occur in an unusual distribution area have a high conspicuousness and whose records are increasing over time. Our rationale is that if a species can be easily recorded, its possibility of not having been detected before is low. Therefore, finding it in unusual sites is a strong indication that the new record represents a change of distribution. (2) Likely change of distribution range: The distribution area and record dynamics indicators are the same as for the previous category, but species conspicuousness is low. Therefore, a species in this category may have gone unnoticed, and we cannot assure that it belongs to the category change of distribution range. (3) Accidental: In this category the first two criteria are the same as in the change of distribution range, which is important to ensure that this species doesn't go unnoticed, but in the criteria of record dynamics the records of the species in the new area are scarce and do not show an increase over time. (4) Knowledge gap: These are species with new records within a known distribution range. In most cases these are species with low conspicuousness, mainly due to both low detectability and abundance, for which they can easily go undetected for long periods. However, in some cases these species have low detectability but their populations can be abundant and their records scarce or increasing. (5) Undetermined: In this category we included species with records in unusual distribution area, low conspicuousness, and scarce dynamics of records, which can justify why they had gone unnoticed until recently. Species records within normal distribution range, with high conspicuousness and increasing records are very unlikely, unless they were species which were locally extinct and with a recent recolonization. Nonetheless, that is not the object of this study (see Tables 2 and 3).

Table 2. Possible combinations of criteria resulting from different indicators used to assign species into categories of new records of birds in the Ecuadorian part of the Tumbesian region in the last two decades.

\begin{tabular}{ccc}
\hline \multicolumn{2}{c}{ Criteria } & Indicator \\
\hline Habitat & Distribution & Distribution area \\
\hline Usual & Normal & Normal \\
Usual & Atypical & Unusual \\
Unusual & Normal & Unusual \\
Unusual & Atypical & Unusual \\
\hline Abundance & Detectability & Conspicuousness \\
\hline Abundant & High & High \\
Abundant & Low & High \\
Rare & High & High \\
Rare & Low & Low \\
\hline
\end{tabular}

Table 3. Combinations of indicators used to classify species into different categories for the new records of birds in the Ecuadorian part of the Tumbesian region in the last two decades.

\begin{tabular}{cccc}
\hline Distribution Area & Conspicuousness & Recording Dynamics & Category \\
\hline Unusual & High & Scarce & Accidental \\
Unusual & High & Increasing & Change of distribution range \\
Unusual & Low & Scarce & Undetermined \\
Unusual & Low & Increasing & Likely Change of distribution range \\
Normal & High & Increasing & Does not apply, unlikely \\
Normal & Low & Increasing & Knowledge gap \\
Normal & High & Scarce & Knowledge gap \\
Normal & Low & Scarce & Knowledge gap \\
\hline
\end{tabular}


After classifying the species in the categories explained above, we divided them into terrestrial and aquatic species. A Chi-Square test was used to evaluate the association between categories and habitat.

\subsection{Validation}

We tested the performance of the proposed methodology using two approaches. First, we used four species for which changes in distribution have been documented. For them, we followed our methodology to test if they can be correctly assigned to the category Change of distribution range. The species used were Passer hispaniolensis, Elanus caeruleus, Columba palumbus, and Streptopelia decaocto, which represent examples of distribution range expansion in the Palearctic region [75-78]. Secondly, we verified whether experts $[42,67-69,72]$ had suggested possible distribution movements of the species classified as Change of distribution range.

\section{Results}

We found 46 bird species that were reported as new records in the Ecuadorian Tumbesian region in the last two decades. Regarding the classification into different categories, 35\% of the species were classified as Accidental (16 species), 24\% were classified as Knowledge gaps (11 species), 22\% as Changes of distribution range (10 species), 15\% as Undetermined (7 species), and $4 \%$ as Likely change of distribution range (2 species) (Table A1).

Among the new records, 18 species were new for the Zapotillo canton and were recorded during field work between 2014 and 2019 (Figure 2). Of these, nine were new records for the Loja province, Ecuador (Table A1).

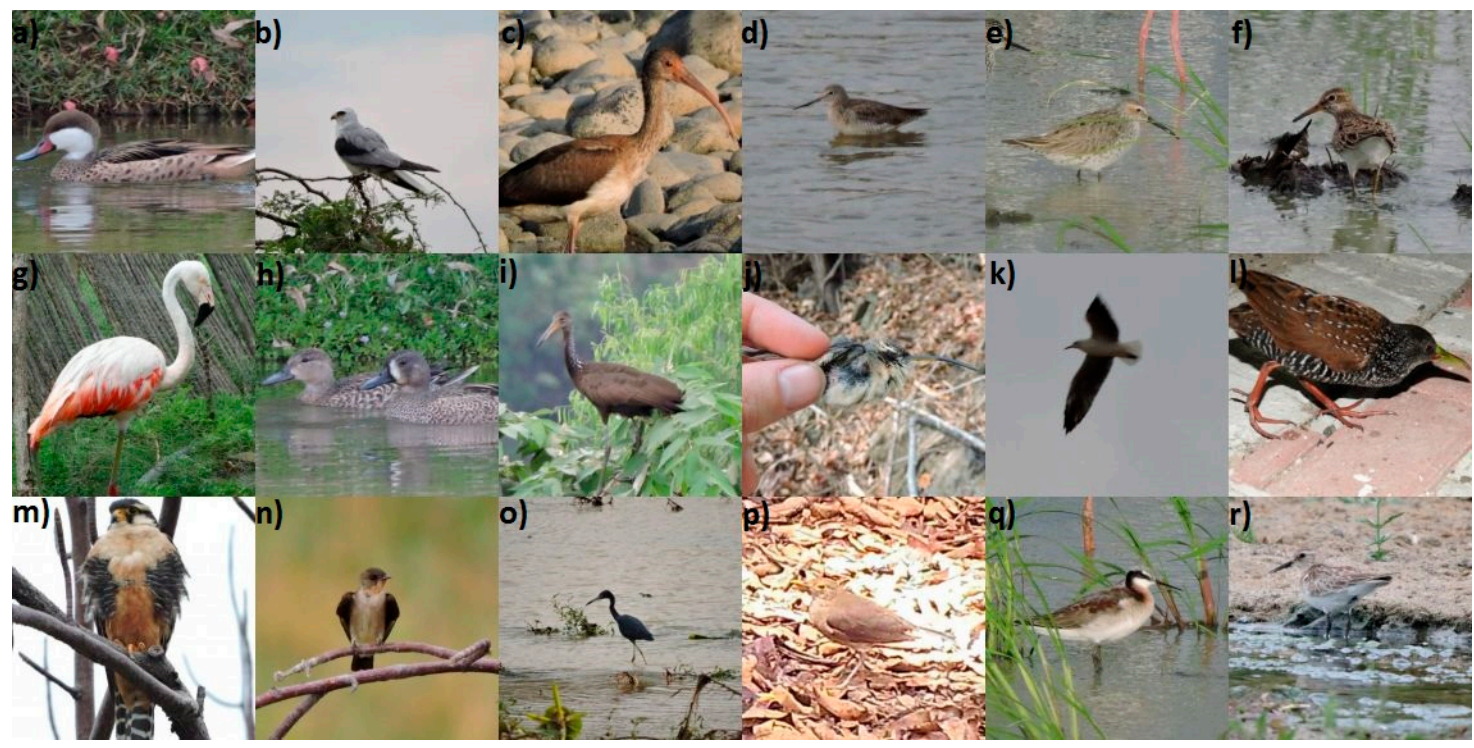

Figure 2. New bird species records in the Zapotillo canton, Loja, southwestern Ecuador. The first nine species $(\mathbf{a}-\mathbf{i})$ were also new records in Loja province, South of Ecuador.

Of the new records, $80 \%$ of the species were related to aquatic ecosystems and the remaining species were classified as terrestrial. The classification in the different record categories was significantly associated with the type of ecosystem $\left(X^{2}=11.54, p_{-}\right.$value $\left.=0.021\right)$. Terrestrial species were mostly classified as Knowledge gap, while aquatic species were mostly classified as Accidental (Figure 3). Of the species classified as Change of distribution range, most were aquatic. 


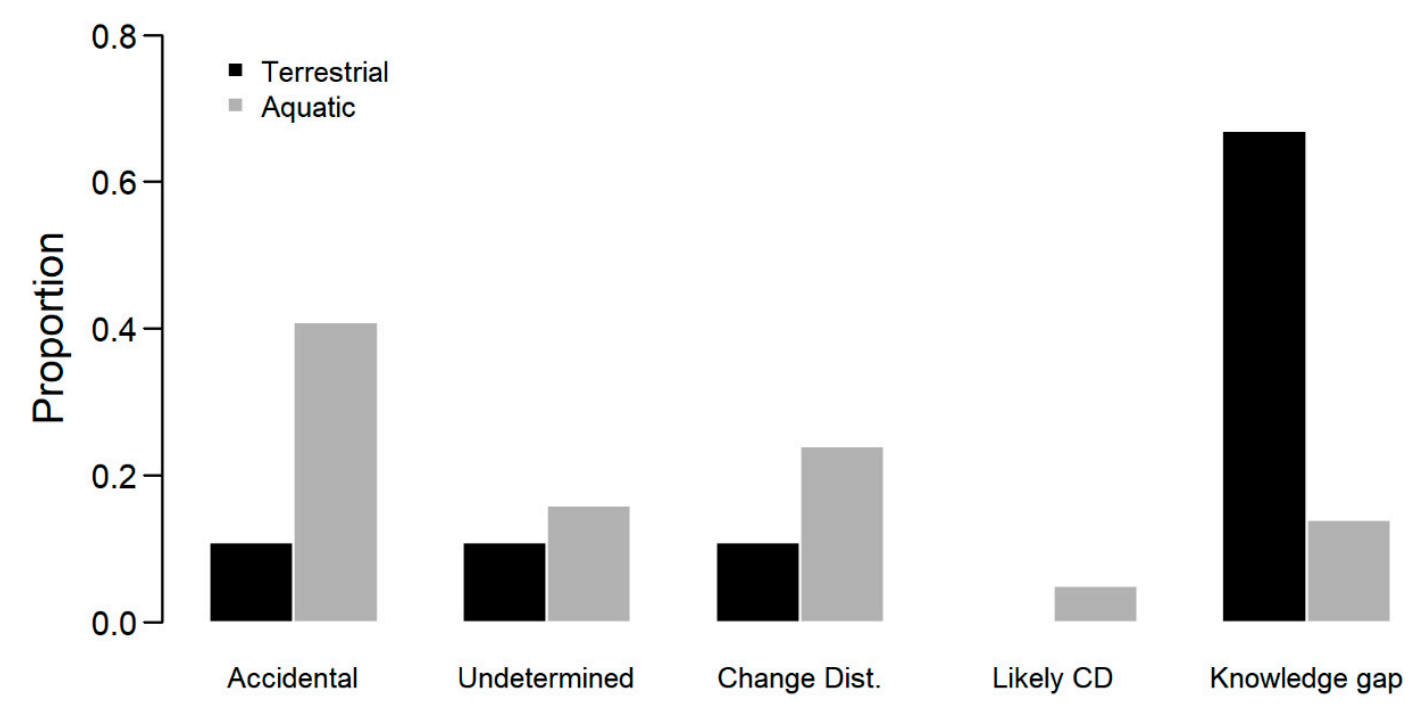

Figure 3. Proportion of species linked to aquatic or terrestrial ecosystems of the 46 new records of bird species recorded for the Ecuadorian part of the Tumbesian region in the last two decades. They are classified according to five categories (Accidental, Undetermined, Change of distribution range (Change Dist.), Likely change of distribution range (Likely CD), and Knowledge gap) denoting the nature of these new records.

The four species used to validate the methodology were classified correctly as Change of distribution range (Table A1). In addition, for $80 \%$ of the species that were classified as Change of distribution range, there were clues that suggested that they are indeed expanding their distribution range.

\section{Discussion}

In the last two decades, new bird records have been reported in the Tumbesian region [42,67-69], a common phenomenon around the world [71]. Our classification protocol provided insights regarding the nature of these records, providing evidence of either changes in the distribution range of species or increase of ornithological knowledge for this region. The validation of our protocol suggests that using the method proposed here it is possible to correctly classify new species records in areas with limited knowledge. This is an efficient and easily applicable methodology, which can be especially useful in areas where long-term studies on biodiversity are scarce, such as the Neotropics.

In our study, $22 \%$ of the species were classified as "Change of distribution range". It is noteworthy that $90 \%$ of the species classified as Change of distribution range were species linked to aquatic ecosystems. In recent years, numerous cases of latitudinal, longitudinal, and altitudinal movements of waterbirds have been reported, both in Ecuador $[58,79,80]$ and in the Neotropics [55]. The movements of these species may be influenced by different events, such as the El Niño-Southern Oscillation (ENSO) phenomenon [81], the pollution of natural wetlands, or the disappearance and appearance of new artificial bodies of water [82]. The only terrestrial species classified as a change of distribution is the White-tailed Kite (Elanus lecurus), a raptor that is benefiting from deforestation in the Tumbesian region [83] and is expanding its range to the south, along the Pacific coast. Furthermore, there are two species (Hydroprogne caspia and Limosa fedoa) considered as Likely change of distribution range, since their number of records are increasing and they are present outside the usual boundaries of their distribution. However, we cannot be sure of this assignment, since they are species which can be misidentified or may have gone unnoticed, due to their low conspicuousness (Table A1).

In the Neotropics, and particularly in southern Ecuador, there is an important lack of information on the distributions and movements of the species [29,56,84]. We classified $24 \%$ of the species as Knowledge gaps (Table A1). Of these species, at least three may have been overlooked in the past (Phaethornis griseogularis, Pardirallus maculatus, and Ciccaba nigrolineata) [85-87]. A similar case is that 
of Phaetornis griseogularis in Colombia [85]. Notable examples of knowledge gaps in southern Ecuador are the recent confirmation of the presence of populations of the Koepcke's Screech-Owl (Megascops koepckeae) in the south inter-Andean region [88], the discovery of the subspecies Red-ruffed Fruitcrow (Pyroderus scutatus masoni) in the southeast of Ecuador [89], and the discovery of a new species for science, the Blue-throated Hillstar (Oreotrochilus cyanolaemus) [90]. It is worth mentioning that the high proportion of terrestrial species classified as Knowledge gaps shows that there is still much to learn about the distribution of the biodiversity in the Ecuadorian tropical dry forests.

Our proposed methodology contributes to understanding the nature of new records in an area. However, the dynamics of species' movements are complex, and our method has some limitations. Firstly, although many species classified as Change of distribution range may be indeed expanding their distribution, our methodology did not allow us to establish which factors are determining those changes. The implementation of long-term capture-recapture studies in the region, together with the promotion of citizen science projects, is an effort that can provide valuable data to better understand the determinants of bird movements in the dry forest of Ecuador. Secondly, global changes can also modify the distribution range of a species by causing local extinctions. Future studies could incorporate analysis of consistent reductions in the number of records of a species in an area to further evaluate potential local extinction. And third, estimating how the number of studies or the number of ornithologist in an area is associated to the dynamic of records of a species could also contribute to discerning knowledge gaps from changes in distribution ranges. Due to a lack of data, it was not possible to directly incorporate such analysis in our methodology, but it could be used in areas that have systematic information about field studies.

We presented a protocol which can be used to better understand if species are moving in response to anthropogenic global change, especially in areas where historical information about biodiversity is scarce. This type of information will be key to implementing effective conservation strategies, designating potential conservation areas, and focusing our attention on the species or groups of species most vulnerable to anthropogenic global change.

Author Contributions: Conceptualization, A.O.-T and C.I.E.; methodology, A.O.-T. and C.I.E.; validation, A.O.-T., C.I.E., B.T., and L.O.-D.; investigation, A.O.-T. and L.O.; writing-original draft preparation, A.O.-T. and C.I.E.; writing-review and editing, A.O.-T., C.I.E., B.T., and L.O.-D.; project administration, C.I.E. and B.T. All authors have read and agreed to the published version of the manuscript.

Funding: Field work was supported by the "Secretaría de Educación Superior, Ciencia, Tecnología e Innovación" (SENESCYT) project "Spatio-temporal responses of bird and bat communities to altitudinal gradients and disturbance in three ecosystems south of Ecuador" (PIC-13-ETAPA-004).

Acknowledgments: We thank Darwin Valle for the realization of the map. We also thank the rangers Darwin Martínez and Alvaro Ludeña for giving us the photos of Pardirallus maculatus and Phoenicopterus chilensis. The authors acknowledge May Platt and Diana Szekely for their help in the English edition of the manuscript.

Conflicts of Interest: The authors declare no conflict of interest. 


\section{Appendix A}

Table A1. Bird species reported as "new records" in the Ecuadorian Tumbesian region in the last two decades (2000-2020). In addition, there were four Palearctic species (Passer hispaniolensis, Elanus caeruleus, Columba palumbus, and Streptopelia decaocto) used to validate the methodology. The "+" indicates a new species for the Zapotillo canton and the " ++ " indicates new species for the Loja province.

\begin{tabular}{|c|c|c|c|c|c|c|c|}
\hline & \multicolumn{2}{|c|}{ Distribution Area } & \multicolumn{2}{|c|}{ Conspicuousness } & \multirow{2}{*}{$\begin{array}{c}\text { Recording Dynamics } \\
\text { Dynamic }\end{array}$} & \multirow[b]{2}{*}{ Category } & \multirow[b]{2}{*}{ Source } \\
\hline Species & Habitat & Distribution & Abundance & Detectability & & & \\
\hline Spatula cyanoptera & Usual & Atypical & Rare & High & Increasing & Change of distribution range & {$[67,68]$} \\
\hline Spatula clypeata & Usual & Atypical & Rare & High & Scarce & Accidental & {$[67,68]$} \\
\hline Netta erythrophthalma & Usual & Atypical & Rare & High & Scarce & Accidental & [67] \\
\hline Aythya collaris & Usual & Atypical & Rare & High & Scarce & Accidental & [67] \\
\hline Aythya affinis & Usual & Atypical & Rare & High & Increasing & Change of distribution range & [67] \\
\hline Anas carolinensis & Usual & Atypical & Rare & High & Scarce & Accidental & [69] \\
\hline Anas bahamensis++ & Unusual & Normal & Abundant & High & Increasing & Change of distribution range & Field work \\
\hline Anas discors++ & Unusual & Normal & Abundant & High & Scarce & Accidental & Field work \\
\hline Phoenicopterus chilensis++ & Unusual & Normal & Rare & High & Increasing & Change of distribution range & Field work \\
\hline Podiceps major & Usual & Atypical & Rare & High & Increasing & Change of distribution range & [67] \\
\hline Phaethornis griseogularis+ & Usual & Normal & Abundant & Low & Scarce & Knowledge gap & Field work \\
\hline Pardirallus maculatus+ & Usual & Normal & Rare & Low & Scarce & Knowledge gap & Field work \\
\hline Numenius americanus & Usual & Atypical & Rare & High & Scarce & Accidental & [68] \\
\hline Limosa fedoa & Usual & Atypical & Rare & Low & Increasing & Likely change of distribution range & {$[67,68,74]$} \\
\hline Haematopus ater & Usual & Atypical & Rare & High & Scarce & Accidental & [68] \\
\hline Chroicocephalus cirrocephalus+ & Unusual & Normal & Abundant & High & Scarce & Accidental & Field work \\
\hline Chroicocephalus philadelphia & Usual & Atypical & Rare & Low & Scarce & Undetermined & {$[68]$} \\
\hline Larus delawarensis & Usual & Atypical & Rare & Low & Scarce & Undetermined & [68] \\
\hline Hydroprogne caspia & Usual & Atypical & Rare & Low & Increasing & Likely change of distribution range & {$[67,68]$} \\
\hline Stercorarius chilensis & Usual & Atypical & Rare & High & Scarce & Accidental & [69] \\
\hline Tringa solitaria & Usual & Normal & Abundant & Low & Scarce & Knowledge gap & [42] \\
\hline Tringa melanoleuca++ & Usual & Normal & Abundant & Low & Scarce & Knowledge gap & Field work \\
\hline Calidris bairdii+ & Unusual & Normal & Rare & Low & Scarce & Undetermined & Field work \\
\hline Calidris himantopus++ & Unusual & Normal & Rare & Low & Scarce & Undetermined & Field work \\
\hline Calidris melanotos++ & Usual & Normal & Rare & Low & Scarce & Knowledge gap & Field work \\
\hline Calidris alpina & Usual & Atypical & Rare & Low & Scarce & Undetermined & [69] \\
\hline Phalaropus tricolor+ & Unusual & Normal & Abundant & High & Scarce & Accidental & Field work \\
\hline
\end{tabular}


Table A1. Cont.

\begin{tabular}{|c|c|c|c|c|c|c|c|}
\hline \multicolumn{3}{|c|}{ Distribution Area } & \multicolumn{2}{|c|}{ Conspicuousness } & \multirow{2}{*}{$\begin{array}{c}\text { Recording Dynamics } \\
\text { Dynamic }\end{array}$} & \multirow[b]{2}{*}{ Category } & \multirow[b]{2}{*}{ Source } \\
\hline Species & Habitat & Distribution & Abundance & Detectability & & & \\
\hline Oceanites oceanicus & Usual & Normal & Rare & Low & Scarce & Knowledge gap & {$[67,68]$} \\
\hline Oceanodroma hornbyi & Usual & Atypical & Rare & Low & Scarce & Undetermined & {$[67,68]$} \\
\hline Thalassarche bulleri & Usual & Atypical & Rare & High & Scarce & Accidental & [69] \\
\hline Platalea ajaja & Unusual & Normal & Rare & High & Increasing & Change of distribution range & [42] \\
\hline Sula leucogaster & Usual & Atypical & Rare & High & Increasing & Change of distribution range & {$[67-69]$} \\
\hline Ardea herodias & Usual & Atypical & Rare & High & Increasing & Change of distribution range & {$[67,68]$} \\
\hline Egretta rufescens & Usual & Atypical & Rare & High & Scarce & Accidental & {$[67,68,73]$} \\
\hline Egretta caerulea+ & Unusual & Normal & Abundant & High & Scarce & Accidental & Field work \\
\hline Aramus guarauna++ & Usual & Atypical & Rare & High & Scarce & Accidental & Field work \\
\hline Plegadis falcinellus & Usual & Atypical & Rare & High & Increasing & Change of distribution range & {$[67,68,74]$} \\
\hline Eudocimus albus++ & Unusual & Normal & Abundant & High & Scarce & Accidental & Field work \\
\hline Elanus leucurus++ & Usual & Atypical & Abundant & High & Increasing & Change of distribution range & Field work \\
\hline Ciccaba nigrolineata & Usual & Normal & Abundant & Low & Scarce & Knowledge gap & [42] \\
\hline Falco femoralis+ & Unusual & Atypical & Rare & High & Scarce & Accidental & Field work \\
\hline Turdus maculirostris+ & Usual & Normal & Abundant & Low & Scarce & Knowledge gap & Field work \\
\hline Stelgidopteryx ruficollis+ & Usual & Normal & Abundant & Low & Scarce & Knowledge gap & Field work \\
\hline Tumbezia salvini & Usual & Normal & Rare & Low & Scarce & Knowledge gap & [67] \\
\hline Tyrannus dominicensis & Usual & Atypical & Rare & Low & Scarce & Undetermined & {$[72,74]$} \\
\hline Sicalis taczanowskii & Usual & Normal & Rare & Low & Scarce & Knowledge gap & [42] \\
\hline Passer hispaniolensis & Usual & Atypical & Abundant & High & Increasing & Change of distribution range & Example, [75] \\
\hline Elanus ceruleus & Usual & Atypical & Abundant & High & Increasing & Change of distribution range & Example, [76] \\
\hline Columba palumbus & Unusual & Atypical & Abundant & High & Increasing & Change of distribution range & Example, [77] \\
\hline Streptopelia decaocto & Usual & Atypical & Abundant & High & Increasing & Change of distribution range & Example, [78] \\
\hline
\end{tabular}




\section{References}

1. Tscharntke, T.; Klein, A.M.; Steffan-Dewenter, I.; Thies, C. Landscape perspectives on agricultural intensification and biodiversity - ecosystem service management. Ecol. Lett. 2005, 8, 857-874. [CrossRef]

2. Flynn, D.F.; Gogol-Prokurat, M.; Nogeire, T.; Molinari, N.; Richers, B.T.; Lin, B.B.; DeClerck, F. Loss of functional diversity under land use intensification across multiple taxa. Ecol. Lett. 2009, 12, 22-33. [CrossRef] [PubMed]

3. Watson, J.E.; Shanahan, D.F.; Di Marco, M.; Allan, J.; Laurance, W.F.; Sanderson, E.W.; Venter, O. Catastrophic declines in wilderness areas undermine global environment targets. Curr. Biol. 2016, 26, 2929-2934. [CrossRef] [PubMed]

4. Tapia-Armijos, M.F.; Homeier, J.; Munt, D.D. Spatio-temporal analysis of the human footprint in South Ecuador: Influence of human pressure on ecosystems and effectiveness of protected areas. Appl. Geogr. 2017, 78, 22-32. [CrossRef]

5. Pimm, S.L.; Jenkins, C.N.; Abell, R.; Brooks, T.M.; Joppa, L.N.; Raven, P.H.; Roberts, C.M.; Sexton, J.O. The biodiversity of species and their rates of extinction, distribution, and protection. Science 2014, 344, 1246752. [CrossRef]

6. Kappelle, M.; Van Vuuren, M.M.; Baas, P. Effects of climate change on biodiversity: a review and identification of key research issues. Biodivers. Conserv. 1999, 8, 1383-1397. [CrossRef]

7. Parmesan, C. Ecological and evolutionary responses to recent climate change. Annu. Rev. Ecol. Evol. Syst. 2006, 37, 637-669. [CrossRef]

8. Heller, N.E.; Zavaleta, E.S. Biodiversity management in the face of climate change: a review of 22 years of recommendations. Biol. Conserv. 2009, 142, 14-32. [CrossRef]

9. Melo, I.; Ochoa-Quintero, J.M.; de Oliveira Roque, F.; Dalsgaard, B. A review of threshold responses of birds to landscape changes across the world. J. Field Ornithol. 2018, 89, 303-314. [CrossRef]

10. Parmesan, C.; Yohe, G. A globally coherent fingerprint of climate change impacts across natural systems. Nature 2003, 421, 37. [CrossRef]

11. Root, T.L.; Price, J.T.; Hall, K.R.; Schneider, S.H.; Rosenzweig, C.; Pounds, J.A. Fingerprints of global warming on wild animals and plants. Nature 2003, 421, 57. [CrossRef] [PubMed]

12. Freeman, B.G.; Scholer, M.N.; Ruiz-Gutierrez, V.; Fitzpatrick, J.W. Climate change causes upslope shifts and mountaintop extirpations in a tropical bird community. Proc. Natl. Acad. Sci. USA 2018, 115, 201804224. [CrossRef] [PubMed]

13. Harris, J.B.C.; Sekercioglu, C.H.; Sodhi, N.S.; Fordham, D.A.; Paton, D.C.; Brook, B.W. The tropical frontier in avian climate impact research. Ibis 2011, 153, 877-882. [CrossRef]

14. Sekercioglu, C.H.; Primack, R.B.; Wormworth, J. The effects of climate change on tropical birds. Biol. Conserv. 2012, 148, 1-18. [CrossRef]

15. Chen, I.C.; Hill, J.K.; Ohlemüller, R.; Roy, D.B.; Thomas, C.D. Rapid range shifts of species associated with high levels of climate warming. Science 2011, 333, 1024-1026. [CrossRef]

16. Freeman, B.G.; Class-Freeman, A.M. Rapid upslope shifts in New Guinean birds illustrate strong distributional responses of tropical montane species to global warming. Proc. Natl. Acad. Sci. USA 2014, 111, 4490-4494. [CrossRef]

17. Beckage, B.; Osborne, B.; Gavin, D.G.; Pucko, C.; Siccama, T.; Perkins, T. A rapid upward shift of a forest ecotone during 40 years of warming in the Green Mountains of Vermont. Proc. Natl. Acad. Sci. USA 2008, 105, 4197-4202. [CrossRef]

18. Zuckerberg, B.; Woods, A.M.; Porter, W.F. Poleward shifts in breeding bird distributions in New York State. Glob. Chang. Biol. 2009, 15, 1866-1883. [CrossRef]

19. Tingley, M.W.; Koo, M.S.; Moritz, C.; Rush, A.C.; Beissinger, S.R. The push and pull of climate change causes heterogeneous shifts in avian elevational ranges. Glob. Chang. Biol. 2012, 18, 3279-3290. [CrossRef]

20. DeLuca, W.V.; King, D.I. Montane birds shift downslope despite recent warming in the northern Appalachian Mountains. J. Ornithol. 2017, 158, 493-505. [CrossRef]

21. Kirchman, J.J.; Van Keuren, A.E. Altitudinal Range Shifts of Birds At the Southern Periphery of the Boreal Forest: 40 Years of Change In the Adirondack Mountains. Wilson J. Ornithol. 2017, 129, 742-753. [CrossRef]

22. Thomas, C.D.; Lennon, J.J. Birds extend their ranges northwards. Nature 1999, 399, 213. [CrossRef] 
23. Archaux, F. Breeding upwards when climate is becoming warmer: no bird response in the French Alps. Ibis 2004, 146, 138-144. [CrossRef]

24. Gregory, R.D.; Willis, S.G.; Jiguet, F.; Voř̌̌šek, P.; Klvan`ová, A.; van Strien, A.; Huntley, B.; Collingham, Y.C.; Couvet, D.; Green, R.E. An indicator of the impact of climatic change on European bird populations. PLoS ONE 2009, 4, e4678. [CrossRef]

25. Devictor, V.; Julliard, R.; Couvet, D.; Jiguet, F. Birds are tracking climate warming, but not fast enough. Proc. R. Soc. Lond. B Biol. Sci. 2008, 275, 2743-2748. [CrossRef]

26. Roth, T.; Plattner, M.; Amrhein, V. Plants, Birds and Butterflies: Short-Term Responses of Species Communities to Climate Warming Vary by Taxon and with Altitude. PLoS ONE 2014, 9, e82490. [CrossRef]

27. Pounds, J.A.; Fogden, M.P.L.; Campbell, J.H. Biological response to climate change on a tropical mountain. Nature 1999, 398, 611. [CrossRef]

28. Forero-Medina, G.; Terborgh, J.; Socolar, S.J.; Pimm, S.L. Elevational ranges of birds on a tropical montane gradient lag behind warming temperatures. PLoS ONE 2011, 6, e28535. [CrossRef] [PubMed]

29. Freile, J.F.; Greeney, H.F.; Bonacorsso, E. Current Neotropical ornithology: Research progress 1996-2011. Condor Ornithol. Appl. 2014, 116, 84-96. [CrossRef]

30. Wormworth, J.; Sekercioglu, C.H. Winged Sentinels: Birds and Climate Change, 1st ed.; Cambridge University Press: New York, NY, USA, 2008; pp. 42-63.

31. Giorgi, F. Climate change hot-spots. Geophys. Res. Lett. 2006, 33, L08707. [CrossRef]

32. Hermes, C.; Keller, K.; Nicholas, R.E.; Segelbacher, G.; Schaefer, H.M. Projected impacts of climate change on habitat availability for an endangered parakeet. PLoS ONE 2018, 13, e0191773. [CrossRef]

33. McCain, C.M. Vertebrate range sizes indicate that mountains may be 'higher' in the tropics. Ecol. Lett. 2009, 12, 550-560. [CrossRef] [PubMed]

34. Graham, C.H.; Parra, J.L.; Rahbek, C.; McGuire, J.A. Phylogenetic structure in tropical hummingbird communities. Proc. Natl. Acad. Sci. USA 2009, 106, 19673-19678. [CrossRef] [PubMed]

35. Best, B.J.; Kessler, M. Biodiversity and Conservation in Tumbesian Ecuador and Peru; BirdLife Internacional: Cambridge, UK, 1995.

36. Portillo-Quintero, C.A.; Sánchez-Azofeifa, G.A. Extent and conservation of tropical dry forests in the Americas. Biol. Conserv. 2010, 143, 144-155. [CrossRef]

37. Jara-Guerrero, A.; Maldonado-Riofrío, D.; Espinosa, C.I.; Duncan, D. Beyond the Blame Game: A Restoration Pathway Reconciles Ecologists and Local Leaders Divergent Models of Seasonally Dry Tropical Forest Degradation. Ecol. Soc. 2019, 24, 22. [CrossRef]

38. Tapia-Armijos, M.F.; Homeier, J.; Espinosa, C.I.; Leuschner, C.; de la Cruz, M. Deforestation and forest fragmentation in South Ecuador since the 1970s-losing a hotspot of biodiversity. PLOS ONE 2015, 10, e0133701. [CrossRef]

39. Prieto-Torres, D.A.; Nori, J.; Rojas-Soto, O.R. Identifying priority conservation areas for birds associated to endangered Neotropical dry forests. Biol. Conserv. 2018, 228, 205-214. [CrossRef]

40. Miles, L.; Newton, A.C.; DeFries, R.S.; Ravilious, C.; May, I.; Blyth, S.; Kapos, V.; Gordon, J.E. A global overview of the conservation status of tropical dry forests. J. Biogeogr. 2006, 33, 491-505. [CrossRef]

41. Escribano-Avila, G.; Cervera, L.; Ordóñez-Delgado, L.; Jara-Guerrero, A.; Amador, L.; Paladines, B.; Espinosa, C.I. Biodiversity patterns and ecological processes in Neotropical dry forest: the need to connect research and management for long-term conservation. Neotrop. Biodiv. 2017, 3, 107-116. [CrossRef]

42. Ordóñez-Delgado, L.; Tomás, G.; Armijos-Ojeda, D.; Jara-Guerrero, A.; Cisneros, R.; Espinosa, C.I. Nuevos aportes al conocimiento de avifauna en la región Tumbesina; implicaciones para la conservación de la Reserva de Biosfera del Bosque Seco, Zapotillo, Ecuador. Ecosistemas 2016, 25, 13-23. [CrossRef]

43. Benítez, V.; Sánchez, T. Evaluación ecológica rápida de la avifauna en los bosques secos de La Ceiba y Cordillera Arañitas, provincia de Loja, Ecuador. In Biodiversidad en los bosques secos del suroccidente de la provincia de Loja: un reporte de las evaluaciones ecológicas y socioeconómicas rápidas, 1st ed.; Vázquez, M.A., Larrea, M., Suárez, L., Eds.; EcoCiencia, Ministerio del Ambiente, Herbario Loja y Proyecto Bosque Seco: Quito, Ecuador, 2001; pp. 47-65.

44. Freile, J.F.; Bonaccorso, E.; Santander, T. First nesting report of the West Peruvian Screech-owl (Otus roboratus). Ornitol. Neotrop. 2003, 14, 107-111. 
45. Freile, J.F.; Moreano, M.; Bonaccorso, E.; Santander, T.; Chaves, J. Notas sobre la historia natural, distribución y conservación de algunas especies de aves amenazadas del suroccidente de Ecuador. Cotinga 2004, 21, 18-24.

46. Bonaccorso, E.; Santander, T.; Freile, J.F.; Tinoco, B.; Rodas, F. Avifauna and conservation of the Cerro Negro-Cazaderos area, Tumbesian Ecuador. Cotinga 2007, 27, 61-66.

47. Aguilar, Z. Guía de Vida Silvestre del Área de Conservación y Desarrollo: La Ceiba; Naturaleza y Cultura Internacional: Quito, Ecuador, 2008.

48. Tinoco, B. Estacionalidad de la comunidad de aves en un bosque deciduo tumbesino en el sur occidente de Ecuador. Ornitol. Neotrop. 2009, 20, 157-170.

49. Pratolongo, F.A.; Flanagan, J.N.; Vellinga, W.P.; Durand, N. Notes on the birds of Laquipampa Wildlife Refuge, Lambayeque, Peru. Bull. Br. Ornithol. Club 2012, 132, 162-174.

50. Stager, M.; Lopresti, E.; Pratolongo, F.A.; Ardia, D.R.; Caceres, D.; Cooper, C.B.; Winkler, D.W. Reproductive biology of a narrowly endemic Tachycineta swallow in dry, seasonal forest in coastal Peru. Ornitol. Neotrop 2012, 23, 95-112.

51. LoPresti, E.; Angulo, F. New bird distribution records for Lambayeque, Peru: Nomonyx dominicus (Linneaus, 1766) (Anatidae) and Incaspiza pulchra (Sclater, 1886) (Emberizidae). Check List 2014, 10, 618-620. [CrossRef]

52. Solano-Ugalde, A.; Pérez, V.; Ahlman, R. Primeros registros de la Reinita Gorrinegra (Wilsonia pusilla) en Ecuador. Boletín SAO 2007, 17, 59-62.

53. Athanas, N.; Davies, A.; Miller, R. Discovery of Tumbes Tyrant Tumbezia salvini in Ecuador. Cotinga 2009, 31, 137.

54. Pozo-Zamora, G.M.; Garzón, C.; Echeverría-Vaca, G.; León, K. Nuevos datos de distribución del colibrí Pico Lanza Frentiverde Doryfera ludovicae (Trochilidae) y del Pinzón Oliváceo Arremon castaneiceps (Emberizidae) en la provincia de El Oro, Ecuador. Avances en Ciencias e Ingenierías 2014, 6, 9-12. [CrossRef]

55. Sánchez, J.E.; Zook, J.R.; Carman, E.; Sandoval, L. Information on abundance and occurrence of two recently recorded species of ducks for Costa Rica. Check List 2014, 10, 420-422. [CrossRef]

56. Cisneros-Heredia, D.F. Notes on breeding, behaviour and distribution of some birds in Ecuador. Bull. Br. Ornithol. Club 2006, 126, 153.

57. Jahn, O.; Cosgrove, P.; Cosgrove, C.; Mueses, T.; Santander, T. First record of Brown Pelican Pelecanus occidentalis from the Ecuadorian highlands. Cotinga 2010, 32, 108.

58. Santander, T.; Terán, K.; Mueces, T.; Lara, A.; Llumiquinga, C.; Guevara, E. Registros inusuales de aves costeras en lagunas Altoandinas de Ecuador. Cotinga 2011, 33, 105-107.

59. Guevara, E.A.; Santander, T.; Duivenvoorden, J.F. Seasonal Patterns in Aquatic Bird Counts at Five Andean Lakes of Ecuador. Waterbirds 2013, 35, 636-641. [CrossRef]

60. Bahamonde-Vinueza, D.; Cadena-Ortiz, H.; Cajas-Bermeo, C.; Bonaccorso, E. Unusual records of Cochlearius cochlearius (Linnaeus, 1766) (Aves: Ardeidae) in the Andes of Ecuador. Check List 2014, 10, 687-688. [CrossRef]

61. Ordóñez-Delgado, L.; Reyes-Bueno, F.; Orihuela-Torres, A.; Armijos-Ojeda, D. Registros inusuales de aves en la hoya de Loja, Andes sur del Ecuador. Avances en Ciencias e Ingenierías 2016, 8, 26-36. [CrossRef]

62. Ordóñez-Delgado, L.; González, I.; Armijos-Ojeda, D.; Orihuela-Torres, A. Primer registro de Ardea cocoi (Pelecaniformes: Ardeidae) en la región Andina del sur de Ecuador. Revista CEDAMAZ 2017, 7, 10-15.

63. Holbrook, N.M.; Whitbeck, J.L.; Mooney, H.A. Drought responses of Neotropical deciduous forest trees. In Tropical Deciduous Forests, 1st ed.; Mooney, H.A., Medina, E., Bullock, S.H., Eds.; Cambridge University Press: Cambridge, UK, 1995; pp. 243-276.

64. ICBP. Putting Biodiversity on the Map: Priority Areas for Global Conservation; International Council for Bird Preservation: Cambridge, UK, 1992.

65. Stattersfield, A.J.; Crosby, M.J.; Long, A.J.; Wege, O.E. Endemic Bird Areas of the World: Priorities for Biodiversity Bonservation; BirdLife Internarional Conservation Series No. 7; BirdLife Internarional: Cambridge, UK, 1998.

66. Cerón, C.; Palacios, W.; Valencia, R.; Sierra, R. Las formaciones naturales de la Costa del Ecuador. In Propuesta Preliminar de un Sistema de Clasificación de Vegetación Para el Ecuador Continental; Sierra, R., Ed.; Proyecto INEFAN/GEF-BIRF y EcoCiencia: Quito, Ecuador, 1999.

67. Freile, J.; Ahlman, R.; Brinkuizen, D.; Greenfield, P.; Solano-Ugalde, A.; Navarrete, L.; Ridgely, R. Rare birds in Ecuador: first annual report of the Committee of Ecuadorian Records in Ornithology (CERO). In Avances en Ciencias e Ingenierías; 2013; Volume 5, pp. 24-41. [CrossRef] 
68. Nilsson, J.; Freile, J.F.; Ahlman, R.; Brinkhuizen, D.M.; Greenfield, P.J.; Solano-Ugalde, A. Rare birds in Ecuador: second annual report of the Committee for Ecuadorian Records in Ornithology (CERO). Avances en Ciencias e Ingenierías 2014, 6, 38-50. [CrossRef]

69. Freile, J.F.; Solano-Ugalde, A.; Brinkhuizen, D.M.; Greenfield, P.J.; Lysinger, M.; Nilsson, J.; Navarrete, L.; Ridgely, R.S. Rare Birds in Ecuador: Third Report of the Committee for Ecuadorian Records in Ornithology (CERO). Revista Ecuatoriana de Ornitología, 27. [CrossRef]

70. Ridgely, R.; Greenfield, P.J. The Birds of Ecuador. Status, Ddistribution and Taxonomy, 1st ed.; Cornell University Press: Ithaca, NY, USA, 2001.

71. Del Hoyo, J.; Elliott, A.; Sargatal, J.; Christie, D.A.; de Juana, E. (Eds.) Handbook of the Birds of the World Alive; Lynx Edicions: Barcelona, Spain, 2019; Available online: https://www.hbw.com (accessed on 21 March 2019).

72. Ridgely, R.; Greenfield, P.J. Aves del Ecuador. Guía de Campo, 2nd ed.; Academia de Ciencias Naturales de Filadelfia. Fundación de Conservación Jocotoco: Quito, Ecuador, 2006.

73. McMullan, M.; Navarrete, L. Fieldbook of the Birds of Ecuador Including the Galapagos Islands and Common Mammals, 2nd ed.; Ratty Ediciones: Quito, Ecuador, 2017.

74. eBird Home Page. Available online: https://ebird.org/home (accessed on 10 June 2019).

75. Cramp, S.; Perrins, C.M. The Birds of the Western Palearctic. Crows to Finches; Handbook of the Birds of Europe, the Middle East and North Africa; Oxford University Press: Oxford \& New York, USA, 1994.

76. Balbontin, J.; Negro, J.J.; Sarasola, J.H.; Ferrero, J.J.; Rivera, D. Land-use changes may explain the recent range expansion of the Black-shouldered Kite Elanus caeruleus in southern Europe. Ibis 2008, 150, 707-716. [CrossRef]

77. BirdLife International. European Red List of Birds; Office for Official Publications of the European Communities: Luxembourg, 2015.

78. Bonter, D.N.; Zuckerberg, B.; Dickinson, J.L. Invasive birds in a novel landscape: habitat associations and effects on established species. Ecography 2010, 33, 494-502. [CrossRef]

79. Henry, P.Y. Distributional and altitudinal range extensions for birds from Ecuador. Boletín SAO 2012, 20, 89-106.

80. Félix, F.; Haase, B. A new record of the Blackish Oystercatcher, Haematopus ater ater (Vieillot and Oudart, 1825), in the Gulf of Guayaquil, Ecuador. Check List 2016, 12, 1857. [CrossRef]

81. Sandoval, L.; Acosta-Chaves, V.J.; Ocampo, D.; Mora, C.; Camacho, A.; Martinez, D.; Sanchez, C. Unusual records of waterbirds in Costa Rice: possible connection to El Niño 2015-2016. Mar. Ornithol. 2016, 44, 167-169.

82. Sandoval, L.; Martínez, D.; Ocampo, D.; Pizarro, M.V.; Araya-H, D.; Carman, E.; García-Rodríguez, A. Range expansion and noteworthy records of Costa Rican birds (Aves). Check List 2018, 14, 141. [CrossRef]

83. Bierregaard, R.O., Jr.; Marks, J.S.; Boesman, P.; Kirwan, G.M. White-tailed Kite (Elanus leucurus). In Handbook of the Birds of the World Alive; Del Hoyo, J., Elliott, A., Sargatal, J., Christie, D.A., de Juana, E., Eds.; Lynx Edicions: Barcelona, Spain, 2019; Available online: https://www.hbw.com/node/52968 (accessed on 20 June 2019).

84. Bonaccorso, E.; Arzuza, D.; Buitrón-Jurado, G.; Lucía, A.; Charpentier, M.J.; Piedrahita, P.; Freile, J.F. Range extensions and other noteworthy bird records from the Ecuadorian Andes. Bull. Br. Ornithol. Club 2011, 131, 261-265.

85. Schuchmann, K.L. First record of the Grey-chinned Hermit (Phaethornis griseogularis) west of the Colombian Andes, with notes on the displays of the species. Wilson Bull. 1987, 99, 122-124.

86. Taylor, B. Spotted Rail (Pardirallus maculatus). In Handbook of the Birds of the World Alive; Del Hoyo, J., Elliott, A., Sargatal, J., Christie, D.A., De Juana, E., Eds.; Lynx Edicions: Barcelona, Spain, 2020; Available online: https://www.hbw.com/node/53674 (accessed on 13 January 2020).

87. Gerhardt, R.P.; Gerhardt, D.M.; Bonilla, N.; Flatten, C.J. Black-and-white Owl. In Neotropical Birds of Prey: Biology and Ecology of a Forest Raptor Community; Whitacre, D.F., Ed.; Cornell University Press: Ithaca, NY, USA, 2012; p. 320327.

88. Ordóñez-Delgado, L.; Freile, J.F. First records of Koepcke’s Screech-Owl Megascops koepckeae (Aves: Strigidae) in Ecuador. Revista Ecuatoriana de Ornitología 2019, 5. [CrossRef] 
89. Ordóñez-Delgado, L.; Erazo, S.; González, I.; Armijos-Ojeda, D.; Rosado, D. Pyroderus scutatus masoni (Shaw, 1792) (Aves, Cotingidae): A subspecies of Red-ruffed Fruit crow newly confirmed for Ecuador. Check List 2018, 14, 281. [CrossRef]

90. Sornoza-Molina, F.; Freile, J.F.; Nilsson, J.; Krabbe, N.; Bonaccorso, E. A striking, critically endangered, new species of hillstar (Trochilidae: Oreotrochilus) from the southwestern Andes of Ecuador. Auk Ornithol. Adv. 2018, 135, 1146-1171. [CrossRef]

(C) 2020 by the authors. Licensee MDPI, Basel, Switzerland. This article is an open access article distributed under the terms and conditions of the Creative Commons Attribution (CC BY) license (http://creativecommons.org/licenses/by/4.0/). 